\title{
Cerebral energetic metabolism of individuals with migraine through 31P-MRS: A systematic review
}

\author{
Metabolismo energético cerebral de indivíduos com migrânea através
}

da ${ }^{31}$ P-MRS: Uma revisão sistemática

Mírian Celly Medeiros Miranda Davidi* Letycia dos Santos Neves ${ }^{2}$ Carlúcia Ithamar Fernandes Franco ${ }^{3}$ Rhowena Jane Barbosa de Matos ${ }^{4}$

\footnotetext{
1 Master student in Neuropsychiatry and Behavioral Sciences of the Universidade Federal de Pernambuco (UFPE).

${ }^{2}$ Nutrition Student at Academic Center of Vitoria, Federal University of Pernambuco (UFPE).

${ }^{3}$ Ph.D. Professor at Physiotherapy Department of the State University of Paraiba (UEPB)

${ }^{4}$ Ph.D. Professor of the Physical Education Nucleus of the Academic Center of Vitoria, Federal University of Pernambuco (UFPE).
}

\section{${ }^{*}$ Correspondence}

Mírian Celly Medeiros Miranda David

E-mail: miriancelly@hotmail.com

Received: February 20, 2019.

Accepted: February 26, 2019.

\begin{abstract}
Introduction: Migraine has a neurological origin and is characterized by failure of central modulation leading to neuronal hyperexcitability. Among the factors related to such excitability is the mitochondrial dysfunction that has been considered since the 1980s. Objective: To investigate changes in the cerebral energetic metabolism of individuals with migraine through phosphorus magnetic resonance spectroscopy ( ${ }^{31} \mathrm{P}-\mathrm{MRS}$ ). Methods: It was searched articles on Pubmed, Web of Science and Science Direct betweenof June, 2018 and February, 2019. There was no restriction regarding the year of publication and language. The combination of the descriptors used for this systematic review was: Migraine AND Magnetic resonance spectroscopy [MESH]. The inclusion criteria chosen were: original articles using ${ }^{31} \mathrm{P}-\mathrm{MRS}$ in individuals diagnosed with migraine (with and/or without aura); studies with adults between 18 and 60 years of age diagnosed with episodic or chronic migraine; with control group of individuals without migraine and without pathologies or conditions that would interfere in the results. Excluded were articles: incomplete or unpublished; animal studies; and research protocol articles. Results: Of the 319 articles found, nine were selected. The sample totaled 216 individuals with migraine (53.7\% without aura) and 233 healthy individuals in the control group. It was verified a reduction of phosphocreatine, phosphorylation potential, $\mathrm{Mg}^{2+}$ and ATP, whereas it was observed increase of inorganic phosphate and ADP. Conclusion: There are alterations in cerebral energetic metabolism in individuals with migraine, revealing mitochondrial dysfunction. However, it is needed more studies with higher quality and analysis of the relationships with the socio-demographic and clinical variables.
\end{abstract}

Keywords: Migraine; Phosphorus Magnetic Resonance Spectroscopy; ${ }^{31} \mathrm{P}-\mathrm{MRS}$; Brain Energy Metabolism; Mitochondrial Dysfunction.

\section{RESUMO}

Introdução: A migrânea tem origem neurológica e é caracterizada por falha na modulação central, levando à hiperexcitabilidade neuronal. Entre os fatores relacionados a essa excitabilidade está a disfunção mitocondrial considerada desde os anos 80. Objetivo: Investigar alterações no metabolismo energético cerebral de indivíduos com enxaqueca por espectroscopia de ressonância magnética com fósforo ( ${ }^{31} \mathrm{P}-\mathrm{MRS}$ ). Métodos: Foram pesquisados artigos no Pubmed, Web of Science e Science Direct entre junho de 2018 e fevereiro de 2019. Não houve restrição quanto ao ano de publicação e idioma. A combinação dos descritores utilizados para esta revisão sistemática foi: Migraine AND Magnetic resonance spectroscopy [MESH]. Os critérios de inclusão escolhidos foram: artigos originais utilizando ${ }^{31} \mathrm{P}-\mathrm{MRS}$ em indivíduos com diagnóstico de migrânea (com e/ou sem aura); estudos com adultos entre 18 e 60 anos diagnosticados com enxaqueca episódica ou crônica; com grupo controle de indivíduos sem migrânea e sem patologias ou condições que interferissem nos resultados. Foram excluídos os artigos: incompletos ou inéditos; estudos em animais; e artigos de protocolo de pesquisa. Resultados: Dos 319 artigos encontrados, nove foram selecionados. A amostra totalizou 216 indivíduos com migrânea (cerca de 53,7\% sem aura) e 233 indivíduos saudáveis no grupo controle. Verificou-se uma redução de fosfocreatina, potencial de fosforilação, $\mathrm{Mg}^{2+}$ e ATP, enquanto se observou um aumento de fosfato inorgânico e ADP. Conclusão: Existem alterações no metabolismo energético cerebral em indivíduos com migrânea, revelando disfunção mitocondrial. Porém, são necessários mais estudos com maior qualidade e análise das relações com as variáveis sociodemográficas e clínicas.

Descritores: Enxaqueca; Espectroscopia de Ressonância Magnética de Fósforo; ${ }^{31}$ P-MRS; Metabolismo da Energia Cerebral; Disfunção Mitocondrial. 


\section{INTRODUCTION}

According to the World Health Organization (WHO), 50 to $75 \%$ of individuals between 18 and 65 years old presented at least one headache crisis per year in the world, $30 \%$ of them with reports of migraine attacks. Still according to the $\mathrm{WHO}, 1.7 \%$ to $4 \%$ of adults in the world population present chronic headache ( $\geq 15$ days/month). ${ }^{1}$

Migraine has a neurological origin and is characterized by a failure in central modulation that leads to neuronal hyperexcitability, ${ }^{2}$ it has moderate to severe pain intensity, usually with pulsatile character, presenting predominantly in hemicranial form, with a duration of 4 to 72 hours. $^{3}$

The relationship between migraine and mitochondrial dysfunction has been considered since the 1980s.4 Changes in mitochondrial functionality would lead to high intracellular $\mathrm{Ca}^{2+}$ penetration, phosphorylation deficiency, and excessive free radical production causing energy failure in neurons and astrocytes, triggering, among other factors, the Cortical Spreading Depression involved with migraine. ${ }^{5}$

In addition, mitochondrial impairments are presented in muscle biopsy of individuals with migraine, as well as, therapeutic strategies focused on the improvement of mitochondrial metabolism are effective in the treatment of migraine, such as riboflavin, coenzyme Q10, magnesium, etc. ${ }^{5}$

In this context, phosphorus magnetic resonance spectroscopy ( ${ }^{31} \mathrm{P}-\mathrm{MRS}$ ) is a non invasive technique used to investigate cerebral energetic metabolism in vivo6 Mitochondrial functionality is verified through the intracellular levels of adenosine diphosphate (ADP), phosphocreatine (PCr), inorganic phosphate (Pi), phosphorylation potential (PP), $\mathrm{pH}$ and $\mathrm{Mg}^{2+}$ factors that are indispensable for creatine kinase balance. 7,8

Despite this context, there is still no consensus of the possible mechanisms related to changes in the energy metabolism of individuals with migraine, such as whether this relationship actually exists at the brain level, whether mitochondrial dysfunction would be related to the onset of migraine or it would be the consequence.

Thus, this systematic review aimed to investigate changes in cerebral energetic metabolism of individuals with migraine through ${ }^{31} \mathrm{P}-\mathrm{MRS}$, with the hypothesis that individuals with migraine would have altered rates of $\mathrm{ADP}, \mathrm{PCr}, \mathrm{Pi}$ and $\mathrm{Mg}^{2+}$ when compared with a control group, suggesting dysfunction in mitochondrial activity.

\section{METHODS}

The study is a Systematic Review developed between June, 2018 and February, 2019, registered in PROSPERO as CRD42018112763. The review was carried out to answer the reasearch guiding question: Are there changes in cerebral energy metabolism in individuals with migraine? In order to answer this question, the acronym PICOS was used to guide the review ( $P$ : Individuals with Migraine, I: ${ }^{31} \mathrm{P}-\mathrm{MRS}, \mathrm{C}$ : individuals without migraine, $\mathrm{O}$ : Alterations in cerebral energy metabolism, S: Transversal studies).
Searches were performed on Pubmed and ScienceDirect by combining the descriptors: Migraine AND Magnetic Resonance Spectroscopy [MESH]. It was selected articles without restriction of year of publication and language. The search and selection of articles according to the eligibility criteria was described in the flowchart based on the Preferred Reporting Items for Systematic Reviews and Meta-Analyzes (PRISMA)9 model (Figure 1).

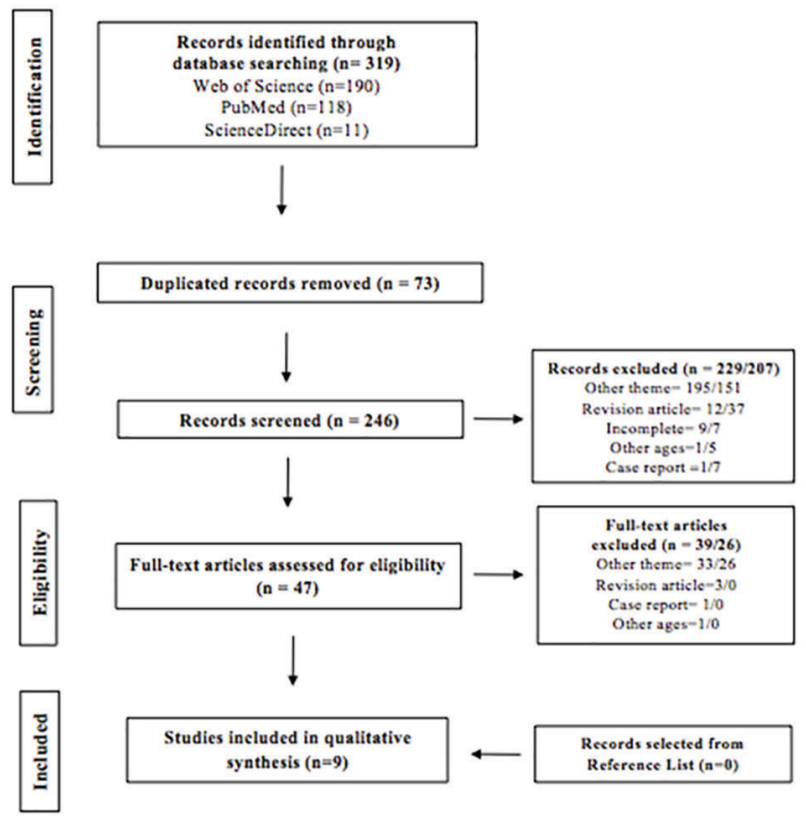

Figure 1. Flowchart of articles selection. Source: Research Data.

The inclusion criteria chosen were: original articles using phosphorus magnetic resonance spectroscopy ( ${ }^{31} \mathrm{P}-\mathrm{MRS}$ ) in individuals diagnosed with migraine (with and/ or without aura); studies with adults between 18 and 60 years of age diagnosed with episodic or chronic migraine; with control group of individuals without migraine and without pathologies or conditions that would interfere in the results. Excluded were articles: incomplete or unpublished; animal studies; and research protocol articles.

The search and selection of the articles according to the eligibility criteria was done independently by two evaluators (MD and LN), in case of disagreement, they discussed and entered into a consensus. When the disagreement between the two initial evaluators remained, the third evaluator (RM) decided whether or not to include the article in question. At the end of the selection, the eligibility of the studies included in the reference list of the selected articles was verified. The flowchart used, which presents in detail the selection process, follows the model PRISMA ${ }^{34}$ (Figure 1).

The selected articles were evaluated according to the Strengthening the Reporting of Observational Studies in Epidemiology Statement - STROBE Statement ${ }^{10}$ by the evaluators (MD and $L N$ ) independently. There was agreement of $43.6 \%$ among the evaluators in the title and abstract reading stage. In the article reading phase, there 
was an initial agreement of $61.5 \%$ and, after discussion, the decision resulted in 9 articles.

The selected studies presented different methods and variables, making it impossible to carry out quantitative analyzes of the studies. Therefore, results such as age, gender, diagnosis, medication, pain intensity, frequency of attacks, imaging techniques and main results were extracted and expressed in tables for qualitative data analysis.

\section{RESULTS}

The search culminated in 319 articles, among which nine studies were selected according to the eligibility criteria of the review. The selected studies presented moderate quality in the writing of the article according to STROBE reaching the average score of 14.6 (66.4\%), with a mean of $64,1 \%$ of agreement (Table 1).

Regarding the characterization of the subjects, the sample totaled 216 individuals with migraine and 233 healthy individuals in the control group. Among the individuals with migraine, it was observed predominance of female (about 78.2\%), adults in middle age, diagnosis of migraine without aura (about 53.7\%) and no medication at the time of the imaging (Table 2).

The studies used devices with varied magnetic field strength, between 1.5 and 3T (Table 3). There were prevalence of individuals in the interictal period (88.5\%), and the occipital area was chosen in the majority of studies for ${ }^{31}$ P-MRS analysis, ${ }^{8,10-15}$ although it was not the only region.

Regarding the results obtained through ${ }^{31} \mathrm{P}-\mathrm{MRS}$, there was a reduction of $\mathrm{PCr}, 1,1,1,16$ Phosphorylation potential, ${ }^{8,16} \mathrm{Mg}^{2+},{ }^{8,11-13}$ and ATP, ${ }^{8,12}$ whereas there was an increase in $\mathrm{Fi}^{8,16}$ and $\mathrm{ADP} 8,16$. In addition, there was a reduction in $\mathrm{Pcr} / \mathrm{Pi}$ and $\mathrm{Pcr} / \mathrm{TP}$ (TP: total phosphorus) in the ictal phase; on the other hand, in the ictal and interictal phase there was an increase in $\mathrm{Pi} / \mathrm{TP}^{14}$ and $\uparrow \mathrm{pMg}$ at ictal stage, ${ }^{17}$ suggesting mitochondrial dysfunction. Other studies did not find statistical diferences in terms of PCr/Pi, PCr/ATP, Pi/ATP and $\mathrm{pH}^{18,15}$

\section{DISCUSSION}

The findings of the review support the initial hypothesis that suggests the existence of a dysfunction in cerebral energetic metabolism of individuals with migraine. The reduced energy potential observed in individuals with migraine was assumed to result from reduced mitochondrial reserve, which is a biochemical substrate for susceptibility to migraine attacks."

At rest, ATP is the result of the balance between its use and synthesis. ATP is almost exclusively the product of mitochondrial oxidative phosphorylation, requiring glucose and oxygen as a supply. Changes in PCr leads to an imbalance between the synthesis and delivery of ATP, since ADP is refosphorylated by the creatine kinase reaction, converting $\mathrm{PCr}$ to creatine.${ }^{16}$ On the other hand, $\mathrm{Mg}^{2+}$ is important because it binds to ATP so that the ATP can be active, necessitating ideal levels of $\mathrm{Mg}^{2+16},{ }^{2}$ which has not been seen in individuals with migraine.
Mitochondrial dysfunctions and disturbances in magnesium metabolism at the cerebral and systemic level would lead to a neuronal hyperexcitability already observed in individuals with migraine." Magnesium is an important component in the human metabolism, it is an essential cofactor for more than 300 biochemical reactions. ${ }^{19}$ These reactions include cellular energy production and storage stabilization of mitochondrial membranes $20-22$

The $\mathrm{Mg}^{2+}$ has membrane stabilizing properties and is fundamental in the function of several ATPases, especially in the $\mathrm{Na}^{+} / \mathrm{K}^{+}$ATPase that controls the $\mathrm{Na}^{+}$pump. Neuronal hyperexcitability would be a result of the reduction of $\mathrm{Mg}^{2+}$ levels that would justify the appearance of Cortical Spreading Depression and the increased sensitivity to the factors that trigger migraine. In addition, $\mathrm{Mg}^{2+}$ regulates brain excitation and/or inhibition by potentiating the gamma-aminobutyric acid (GABA) receptors, thus the reduction of $\mathrm{Mg}^{2+}$ would lead to hyperexcitability by reducing the inhibitory function of GABA. ${ }^{23,24}$

The reduction of free $\mathrm{Mg}^{2+}$ induces the increase of $A D P$, essential in the regulation of mitochondrial ATP production. High levels of ADP, in turn, induce high rates of oxidation in an attempt to return to homeostasis. ${ }^{12}$ Despite the repercussion of $\mathrm{Mg}^{2+}$, Lodi et al.,.2 based on their findings, argue that therapies that increase the efficiency of the production of Mitochondrial ATP would be more advantageous than treatments based on the administration of magnesium.

Because of the importance of $\mathrm{Mg}^{2+}$ for energy production, it may have a special role in the pathogenesis of migraine. Nevertheless, it is seen that $\mathrm{Mg}^{2+}$ medication is useful in some cases of migraine ${ }^{25-29}$

The predominance of the adoption of the occipital region for analysis through ${ }^{31} \mathrm{P}-\mathrm{MRS}$ would be in the fact that it has regional cerebral metabolic oxygen rate higher when compared to other cortical areas. Likewise, the regional cerebral metabolic glucose rate is higher in the occipital white matter and visual cortex than in other areas, and the latter one remains without metabolic changes with age. ${ }^{30,31}$

The reason to some studies not verify alterations on cerebral energetic metabolism could be the brain region choosen to investigate. Changes in energy metabolism in migraineurs have been shown in muscle and platelets ${ }^{6,32-34}$ defending a generalized character of energetic metabolism alteration in individuals with migraine that would unlikely exclude the brain.

Some studies found relations between energy metabolism in complicated types of migraine, such as prolonged aura, stroke migraine or hemiplegic migraine $e^{6,11,21,8,34,35}$ Therefore, rather than influencing the susceptibility to developing a migraine attack, changes in energy metabolism would determine the clinical characteristics of an attack. ${ }^{18}$ Probably because of that, some treatments with magnesium do not show good results in the relieving migraine attacks. ${ }^{36-38}$

Another assumption is that the energetic metabolism alterations verified in some individuals diagnosed with typical or classical migraine could be signals to a possible 


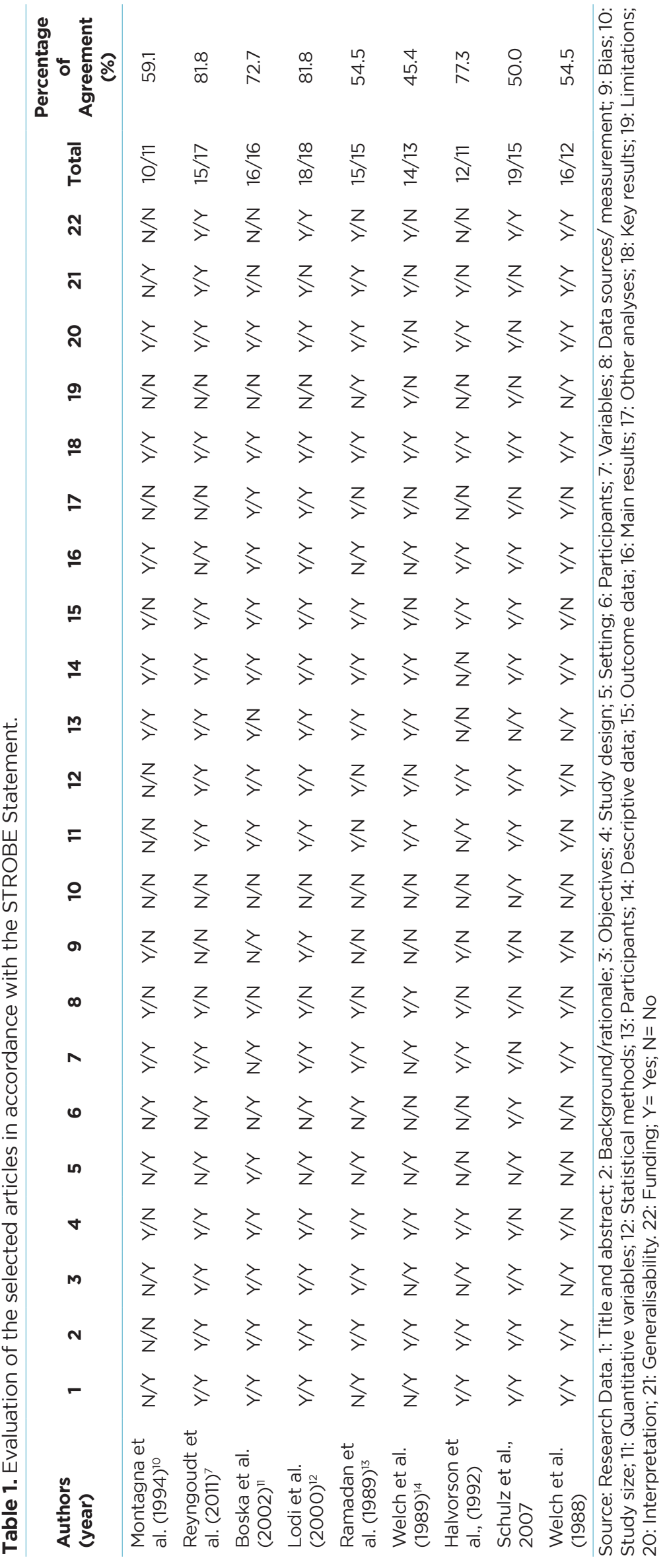


Table 2. Characteristics of the individuals in the selected studies.

\begin{tabular}{|c|c|c|c|c|c|c|c|c|}
\hline $\begin{array}{l}\text { Authors } \\
\text { (year) }\end{array}$ & Subjects & Sex & Age & $\begin{array}{l}\text { Migraine } \\
\text { Type }\end{array}$ & $\begin{array}{l}\text { Migraine } \\
\text { Duration }\end{array}$ & $\begin{array}{c}\text { Pain } \\
\text { Intensity }\end{array}$ & $\begin{array}{c}\text { Attacks } \\
\text { Frequency }\end{array}$ & Medication \\
\hline $\begin{array}{l}\text { Montagna } \\
\text { et al. }(1994)^{9}\end{array}$ & $\begin{array}{c}40 \\
(E: 22 ; \\
C: 18) w\end{array}$ & $\begin{array}{l}\text { E: 19F; } \\
\text { C: 19F. }\end{array}$ & $\begin{array}{c}\mathrm{E}: 34.0 \pm \\
10.0 ; \\
\mathrm{C}: 34.0 \pm \\
18.0\end{array}$ & MwoA (22) & $\begin{array}{c}19.0 \pm 10.0 \\
\text { anos }\end{array}$ & $x$ & $\begin{array}{c}3.6 \pm 1.8 \\
\text { attacks/ } \\
\text { month }\end{array}$ & Without medication \\
\hline $\begin{array}{l}\text { Reyngoudt } \\
\text { et al. }(2011)^{7}\end{array}$ & $\begin{array}{c}45 \\
(E: 19 ; \\
C: 26)\end{array}$ & $\begin{array}{l}\text { E: 18F; } \\
\text { C: } 15 F\end{array}$ & $\begin{array}{c}\mathrm{E}: 32.3 \pm 12.1 \\
\mathrm{C}: 27.6 \pm \\
10.9\end{array}$ & MwoA (19) & $x$ & $x$ & $x$ & $\begin{array}{c}\text { Without } \\
\text { prophylactic } \\
\text { medication }\end{array}$ \\
\hline $\begin{array}{l}\text { Boska et al. } \\
(2002)^{* 11}\end{array}$ & $\begin{array}{c}78 \\
(E: 38 ; \\
C: 40)\end{array}$ & $\begin{array}{l}\mathrm{E}: 32 \mathrm{~F} \\
\mathrm{C}: 27 \mathrm{~F}\end{array}$ & $\begin{array}{c}\text { E: MWA } \\
(40.9 \pm 8.4) \\
\text { MwoA (35.7 } \\
\pm 9.5) ; C: \\
37.5 \pm 11.3 .\end{array}$ & $\begin{array}{l}\text { MWA (19), } \\
\text { MwoA (19) }\end{array}$ & $x$ & $x$ & $x$ & Without medication \\
\hline $\begin{array}{l}\text { Lodi et al. } \\
(2000)^{* 12}\end{array}$ & $\begin{array}{c}94 \\
(E: 58 \\
C: 36)\end{array}$ & $\begin{array}{l}\mathrm{E}: 4 \mathrm{OF} \\
\mathrm{C}: ?\end{array}$ & $\begin{array}{c}\text { E: MWA } \\
(23.0 \pm 2.0) \\
\text { MwoA }(32.0 \\
\pm 2.0) ; C: \\
36.0 \pm 3.0 .\end{array}$ & $\begin{array}{l}\text { MWA (37), } \\
\text { MwoA (21) }\end{array}$ & $\begin{array}{l}\text { MWA: } 11.0 \\
\pm 2.0 \text { anos; } \\
\text { MwoA: } 18.0 \\
\pm 2.0 \text { anos. }\end{array}$ & $x$ & $x$ & Without medication \\
\hline $\begin{array}{l}\text { Ramadan et } \\
\text { al. }(1989)^{13}\end{array}$ & $\begin{array}{c}44 \\
(E: 19 ; \\
C: 25)\end{array}$ & $\begin{array}{l}\text { E: 17F; } \\
\text { C: } 15 F\end{array}$ & $\begin{array}{c}\text { E: MWA } \\
(37.1 \pm 13.2) \\
\text { MwoA (34.3 } \\
\pm 9.7) ; \text { C: } \\
43.4 \pm 18.2\end{array}$ & $\begin{array}{l}\text { MWA (8), } \\
\text { MwoA (11) }\end{array}$ & $x$ & $x$ & $x$ & $\begin{array}{l}\text { Individuals did not } \\
\text { use analgesics } 4 \\
\text { hours before the } \\
\text { imaging. Some } \\
\text { used prophylactic } \\
\text { medication. }\end{array}$ \\
\hline $\begin{array}{l}\text { Welch et al. } \\
(1989)^{14}\end{array}$ & $\begin{array}{c}47 \\
(\mathrm{E}: 20 ; \\
\text { C: } 27)\end{array}$ & $\begin{array}{l}\text { E: 18F; } \\
\text { C: } 17 F\end{array}$ & $\begin{array}{c}\text { E: MWA } \\
(37.1 \pm 13.2) \\
\text { MwoA (37.2 } \\
\pm 12.0) ; \mathrm{C}: \\
45.1 \pm 17.6 .\end{array}$ & $\begin{array}{l}\text { MWA (8), } \\
\text { MWOA (12) }\end{array}$ & $x$ & $x$ & $x$ & $\begin{array}{l}\text { Individuals did not } \\
\text { use analgesics } 4 \\
\text { hours before the } \\
\text { imaging. Some } \\
\text { used prophylactic } \\
\text { medication. }\end{array}$ \\
\hline $\begin{array}{l}\text { Halvorson } \\
\text { et al., } \\
(1992)^{*}\end{array}$ & $\begin{array}{l}28 \\
(E: 10 ; \\
C: 18)\end{array}$ & $x$ & $x$ & $x$ & $x$ & $x$ & $x$ & $x$ \\
\hline $\begin{array}{l}\text { Schulz et al., } \\
(2007)^{*}\end{array}$ & $\begin{array}{l}26 \\
(E: 10 ; \\
C: 16)\end{array}$ & $\begin{array}{l}E: 7 F \\
C: 8 F\end{array}$ & $\begin{array}{c}\text { E: } 42.7 \pm \\
13.7 \\
\text { C: } 39.0 \pm \\
15.0\end{array}$ & MWA (10) & $\begin{array}{c}\leq 1 \mathrm{~h}(6) \\
>1 \mathrm{~h} \leq 24 \mathrm{~h} \\
\quad(2) \\
>24 \mathrm{~h} \\
\leq 7 \mathrm{days}(1) ; \\
>7 \mathrm{~h}(1)^{* *}\end{array}$ & $x$ & $\begin{array}{l}\geq 1 \text { attacks/ } \\
\text { month (3); } \\
<1 \text { attacks/ } \\
\text { month ( } 7)\end{array}$ & $x$ \\
\hline $\begin{array}{l}\text { Welch et al. } \\
\text { (1988) }\end{array}$ & $\begin{array}{c}47 \\
(\mathrm{E}: 20 ; \\
\text { C: } 27)\end{array}$ & $\begin{array}{l}\text { E: 18F; } \\
\text { C: } 17 F\end{array}$ & $\begin{array}{c}\text { E: MWA } \\
(37.1 \pm 13.2) \\
\text { MwoA (37.2 } \\
\pm 12.0) ; C: \\
45.1 \pm 17.6 .\end{array}$ & $\begin{array}{l}\text { MWA (8), } \\
\text { MwoA (12) }\end{array}$ & $x$ & $x$ & $x$ & $\begin{array}{l}\text { Individuals did not } \\
\text { use analgesics } 4 \\
\text { hours before the } \\
\text { imaging. Some } \\
\text { used prophylactic } \\
\text { medication. }\end{array}$ \\
\hline
\end{tabular}

Source: Research Data. 1: Title and abstract; 2: Background/rationale; 3: Objectives; 4: Study design; 5: Setting; 6: Participants; 7: Variables; 8: Data sources/ measurement; 9: Bias; 10: Study size; 11: Quantitative variables; 12: Statistical methods; 13: Participants; 14: Descriptive data; 15: Outcome data; 16: Main results; 17: Other analyses; 18: Key results; 19: Limitations; 20: Interpretation; 21: Generalisability. 22: Funding; $Y=$ Yes; $N=$ No

progression to a complicated migraine. Knowing the suscetibility to future migraine stroke episode or a progression to a prolonged aura crisis or another type of complicated migraine would help to plan a more specific treatment for each situation. In this way, with more studies at the field, the ${ }^{31}$-RMS could became a search tool to determine individuals at risk to develop a complicated migraine.

This review presented some limitations, such as the necessity to consider subgroups of interest in the articles with various subgroups of complicated migraine. In some articles, it was not possible to find all the information that was intended (age, gender, medication, duration, frequency neither intensity of pain). Furthermore, it was not possible to apply a specific tool of assessment risk of bias neither to develop a meta-analysis due to the variability of the results.

Despite the similarities of the conclusions obtained with the selected articles, it is necessary to carry out more 
Table 3. Characteristics of selected studies.

\begin{tabular}{|c|c|c|c|c|c|}
\hline Authors (year) & $\begin{array}{l}\text { Ictal/interictal } \\
\text { condition }\end{array}$ & $\begin{array}{l}\text { 31P-MRS } \\
\text { Instrument }\end{array}$ & Region & Results & Conclusions \\
\hline $\begin{array}{l}\text { Montagna et al. } \\
(1994)^{9}\end{array}$ & Interictal & 1.5T, Signa & Occipital lobes & $\begin{array}{l}\downarrow P C r ; \uparrow P i ; \uparrow A D P ; \uparrow \vee / \\
\quad V m a ́ x ; \downarrow P P\end{array}$ & $\begin{array}{c}\text { Presence of unstable metabolic } \\
\text { status in brain cells, indicating a } \\
\text { defect in the energy metabolism } \\
\text { of individuals with migraine } \\
\text { without aura. }\end{array}$ \\
\hline $\begin{array}{l}\text { Reyngoudt et al. } \\
(2011)^{7}\end{array}$ & Interictal & 3T, Siemes & $\begin{array}{l}\text { Medial occipital } \\
\text { lobe }\end{array}$ & $\begin{array}{l}\downarrow P C r ; \uparrow P i ; \downarrow A T P ; \\
\uparrow A D P ; \downarrow P P ; \downarrow M^{2+}\end{array}$ & $\begin{array}{l}\text { Disturb in the energetic } \\
\text { metabolism of individuals with } \\
\text { migraine. The reduction of ATP } \\
\text { indicates a possible participation } \\
\text { of mitochondria in the } \\
\text { pathophysiology of migraine. }\end{array}$ \\
\hline $\begin{array}{l}\text { Boska et al. } \\
(2002)^{* 11}\end{array}$ & Interictal & $\begin{array}{l}\text { 3T, Magnex- } \\
\text { SMIS }\end{array}$ & $\begin{array}{l}\text { Calcarine cortex, } \\
\text { temporal gyri, } \\
\text { occipital gyri, frontal } \\
\text { gyri, frontal forceps, } \\
\text { genu of corpus } \\
\text { callosum, occipital } \\
\text { cortex }\end{array}$ & $\begin{array}{c}\text { MwoA: } \uparrow P D E \text { in most } \\
\text { brain regions, } \uparrow \mathrm{Mg}^{2+} \\
\text { in posterior brain } \\
\text { regions. } \\
\text { MWA: } \downarrow \text { PCr in } \\
\text { anterior brain } \\
\text { regions, } \downarrow \mathrm{Mg}^{2+} \\
\text { in posterior brain } \\
\text { regions, but no } \\
\text { consistent changes } \\
\text { in } \mathrm{PME} \text {, } \\
\text { PDE, } \mathrm{Pi} \text {, or } \mathrm{pH} \text {. }\end{array}$ & $\begin{array}{c}\text { No substantial alteration of } \\
\text { energy metabolism, but the } \\
\text { disturbances in } \mathrm{Mg}^{2+} \text { homeostasis } \\
\text { may contribute to brain } \\
\text { hyperexcitability }\end{array}$ \\
\hline $\begin{array}{l}\text { Lodi et al. } \\
(2000)^{* 12}\end{array}$ & Interictal & 1.5T, Signa & Occipital lobes & $\begin{array}{l}\downarrow \text { Cytosolic free } \\
\mathrm{Mg}^{2+}, \downarrow \text { free energy } \\
\text { released by the } \\
\text { reaction of ATP } \\
\text { hydrolysis. }\end{array}$ & $\begin{array}{l}\text { There is mitochondrial } \\
\text { dysfunction in individuals } \\
\text { with migraine secondary to } \\
\text { bioenergetics déficit. }\end{array}$ \\
\hline $\begin{array}{l}\text { Ramadan et al. } \\
(1989)^{13}\end{array}$ & $\begin{array}{c}\text { Ictal (10); } \\
\text { Interictal (9) }\end{array}$ & 1.89T, Bruker & $\begin{array}{l}\text { Frontal, } \\
\text { frontotemporal, } \\
\text { parieto-occipital, } \\
\text { occipital cortex }\end{array}$ & $\begin{array}{l}\downarrow \mathrm{Mg}^{2+} \text {, especially } \\
\text { between controls } \\
\text { and migraineurs } \\
\text { measured during an } \\
\text { attack. No changes } \\
\text { in } \mathrm{pH} \text {. }\end{array}$ & $\begin{array}{l}\text { Low brain } \mathrm{Mg}^{2+} \text { is important in } \\
\text { migraine pathofhysiology. }\end{array}$ \\
\hline \multirow{2}{*}{$\begin{array}{l}\text { Welch et al. } \\
(1989)^{14}\end{array}$} & \multirow{2}{*}{$\begin{array}{l}\text { Ictal (11); } \\
\text { Interictal (9) }\end{array}$} & \multirow{2}{*}{ 1.89T, Bruker } & \multirow{2}{*}{$\begin{array}{l}\text { Frontal, } \\
\text { frontotemporal, } \\
\text { parieto-occipital, } \\
\text { occipital cortex }\end{array}$} & 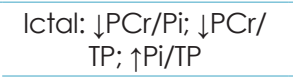 & $\begin{array}{l}\text { Energy phosphate metabolism is } \\
\text { altered during a migraine attack. }\end{array}$ \\
\hline & & & & Interictal: $\uparrow \mathrm{Pi} / \mathrm{TP}$ & \\
\hline $\begin{array}{l}\text { Halvorson et al., } \\
\text { (1992) }\end{array}$ & $\begin{array}{l}\text { Ictal (10); } \\
\text { Interictal (10) }\end{array}$ & $\begin{array}{l}\text { 1.89T, Bruker/ } \\
\text { Oxford } \\
\text { Research }\end{array}$ & $x$ & $\begin{array}{l}\text { Increased variability } \\
\text { of pMg among } \\
\text { migraineurs. } \uparrow \mathrm{pMg} \\
\text { at ictal stage. }\end{array}$ & $\begin{array}{l}\text { Increased variability of pMg } \\
\text { concrntration. The difference } \\
\text { between the means of ictal and } \\
\text { interictal period was statistically } \\
\text { significant. }\end{array}$ \\
\hline $\begin{array}{l}\text { Schulz et al., } \\
\text { (2007)* }\end{array}$ & Interictal & 2T, Bruker & $\begin{array}{l}\text { Level of the basal } \\
\text { ganglia (white and } \\
\text { grey matter) }\end{array}$ & $\begin{array}{c}\text { Non-significant } \\
\text { differences } \\
\text { between control } \\
\text { and migraine with } \\
\text { non-motor aura } \\
\text { in terms of } \mathrm{PCr} / \mathrm{Pi} \\
\text {, } \mathrm{PCr} / \mathrm{ATP}, \mathrm{Pi} / \mathrm{ATP} \\
\text { and } \mathrm{pH}\end{array}$ & $\begin{array}{l}\text { Energy metabolism alterations } \\
\text { may not initiate a migraine attack } \\
\text { but may be involved you the } \\
\text { clinical manifestation of aura. }\end{array}$ \\
\hline $\begin{array}{l}\text { Welch et al. } \\
\text { (1988) }\end{array}$ & $\begin{array}{c}\text { Ictal (11); } \\
\text { Interictal (9) }\end{array}$ & 1.89T, Bruker & $\begin{array}{l}\text { Frontal, } \\
\text { frontotemporal, } \\
\text { parieto-occipital, } \\
\text { occipital cortex }\end{array}$ & $\begin{array}{l}\text { Non-significant } \\
\text { pH differences } \\
\text { between control } \\
\text { and migraine at ictal } \\
\text { neither interictal } \\
\text { phases. }\end{array}$ & $\begin{array}{l}\text { The pain of migraine is unlikely } \\
\text { to be caused by cerebral } \\
\text { vasodilatation induced by } \\
\text { prodromal ischemic brain } \\
\text { acidosis neither other pH } \\
\text { alterations. }\end{array}$ \\
\hline
\end{tabular}

Source: Research Data. PCr: Phosphocreatine; Fi: Inorganic phosphate; ADP: Adenosine diphosphate; V/Vmáx: Rate of ATP synthesis; PP: Phosphorylation potential; ATP: Adenosine triphosphate; MwoA: Migraine without aura; MWA: Migraine with aura; PDE: phosphodiester concentration, PME: phosphomonoester concentration; TP: total phosphorus. * Only the group with migraine (with and/or without aura) and the control group was considered 
studies in the area with higher quality and control of the intervening variables like the medication, not only during the imaging, but also in the routine of the individuals. Likewise, it is important to carry out analyzes regarding the relations of ${ }^{31} \mathrm{P}-\mathrm{MRS}$ results with sociodemographic and clinical variables such as differences between sexes and age; duration of migraine history, pain intensity, frequency of attacks and medication.

In addition, there has been a dearth of recent studies, which are important, given socioeconomic and cultural differences throughout the years, so that nowadays greater knowledge of the disease, modification of the eating and physical habits profile and greater exposure to medicines may change the results.

From the results verified in the selected studies, there are alterations in cerebral energetic metabolism in individuals with migraine, revealing the importance of considering mitochondrial dysfunction as a component in the pathophysiology of this disease. More studies in the area with higher quality, control of intervening variables and analysis of the relationships with the socio-demographic and clinical variables of the affected individuals are necessary.

\section{CONFLICT OF INTEREST AND FINANCIAL SUPPORT}

There was no conflict of interest or funding for this review.

\section{FUNDING}

This research received no specific grant from any funding agency in the public, commercial, or not-forprofit sectors.

\section{ARTICLE HIGHLIGHTS}

- There are alterations in cerebral energetic metabolism in individuals with migraine;

- A mitochondrial dysfunction should beconsidered as a component in the pathophysiology of migraine;

- Energetic metabolism alterations verified in some individuals diagnosed with typical or classical migraine could be signals to a possible progression to a complicated migraine in the future.

- Treatments acting on energetic metabolism, such as magnesium, coenzyme Q10 or riboflavine might be beneficial in the migraine prophylaxis.

- More studies in the area with higher quality, control of intervening variables and analysis of the relationships with the socio-demographic and clinical variables of the affected individuals are necessary.

\section{REFERENCES}

1. World Health Organization. Headache disorders: Fact sheet Updated April 2016. Available in: <http://www.who.int/ mediacentre/factsheets/fs277/en/>. Access in: 31/10/2017 at $12 \mathrm{hO} 5 \mathrm{~min}$.
2. Carod-Artal, FJ. Tackling chronic migraine: current perspectives. Journal of pain research. 2014; 7:185.

3. Headache Classification Committee Of The International Headache Society (IHS). The international classification of headache disorders (beta version). Cephalalgi. 2013; 33(9): 629-808.

4. Montagna, P; Sacquegna, T; Martinelli, P; Cortelli, P; Bresolin, $\mathrm{N}$; Moggio, M; et al. Mitochondrial abnormalities in migraine. Preliminary findings. Headache: The Journal of Head and Face Pain. 1988; 28(7): 477-480.

5. Yorns Jr, Hardison, HH. Mitochondrial dysfunction in migraine. In: Seminars in pediatric neurology. WB Saunders. 2013; 20(3): 188-193.

6. Barbiroli, B; Montagna, P; Cortelli, P; Martinelli, P; Sacquegna, T; Zaniol, P; et al. Complicated migraine studied by phosphorus magnetic resonance spectroscopy. Cephalalgia. 1990; 10(5): 263-272.

7. Stuart S, Griffiths LR. A possible role for mitochondrial dysfunction in migraine. Molecular genetics and genomics. 2012; 287(11-12): 837-844.

8. Reyngoudt, H; Paemeleire, K; Descamps, B; De Deene, $\mathrm{Y}$; Achten, E. ${ }^{31} \mathrm{P}-\mathrm{MRS}$ demonstrates a reduction in highenergy phosphates in the occipital lobe of migraine without aura patients. Cephalalgia. 2011; 31(12):1243-1253.

9. Moher, D; Liberati, A; Tetzlaff, J; Altman, D. G. Preferred reporting items for systematic reviews and meta-analyses: the PRISMA statement. Annals of internal medicine. 2009; 151(4): 264-269.

10. Von Elm, E; Altman, D. G; Egger, M; Pocock, S. J; Gøtzsche, P. C; Vandenbroucke, J. P. The Strengthening the Reporting of Observational Studies in Epidemiology (STROBE) statement: guidelines for reporting observational studies. Annals of internal medicine. 2007; 147(8): 573-577.

11. Boska, M. D; Welch, K. M. A; Barker, P. B; Nelson, J. A; Schultz, L. Contrasts in cortical magnesium, phospholipid and energy metabolism between migraine syndromes. Neurology. 2002; 58(8): 1227-1233.

12. Lodi, R; Iotti, S; Cortelli, P; Pierangeli, G; Cevoli, S; Clementi, $\mathrm{V}$; et al. Deficient energy metabolism is associated with low free magnesium in the brains of patients with migraine and cluster headache. Brain research bulletin. 2000; 54(4): 437-441.

13. Ramadan, N. M; Halvorson, H; Vande-Linde, A; Levine, S. R; Helpern, J. A; Welch, K. M. A. Low brain magnesium in migraine. Headache: The Journal of Head and Face Pain. 1989; 29(7): 416-419.

14. Welch, K. M. A; Levine, S. R; D’andrea, G; Schultz, L. R.; Helpern, J. A. Preliminary observations on brain energy metabolism in migraine studied by in vivo phosphorus 31 NMR spectroscopy. Neurology. 1989; 39(4): 538-538.

15. Welch, K. M. A; Levine, S. R; D’Andrea, G; Helpern, J. A. Brain $\mathrm{pH}$ in migraine: An in vivo phosphorus-31 magnetic resonance spectroscopy study. Cephalalgia. 1988; 8(4): 273-277.

16. Montagna, P; Cortelli, P; Monari, L; Pierangeli, G; Parchi, $\mathrm{P}$; Lodi, R; et al. ${ }^{31} \mathrm{P}-$ Magnetic resonance spectroscopy in migraine without aura. Neurology. 1994; 44(4): 666.

17. Halvorson, H. R.; Vande Linde, A. M. Q; Helpern, J. A.; Welch, K. M. A. Assessment of magnesium concentrations by ${ }^{31} \mathrm{P}$ NMR in vivo. NMR in biomedicine. 1992; 5(2): 53-58.

18. Schulz, U. G; Blamire, A. M; Corkill, R. G; Davies, P; Styles, P; Rothwell, P. M. Association between cortical metabolite levels and clinical manifestations of migrainous aura: an MR-spectroscopy study. Brain. 2007; 130(12): 3102-3110.

19. Elin RJ. Magnesium: the fifth but forgotten electrolyte. Am J Clin Pathol. 1994; 102: 616-622.

20. Rude RK, Shils ME. Modern Nutrition in Health and Disease. 2006; 10: 223-248 
21. Welch, K. M. A.; Ramadan, Nabih M. Mitochondria, magnesium and migraine. Journal of the neurological sciences. 1995; 134 (1-2): 9-14.

22. Pardutz, Arpad; Vecsei, Laszlo. Should magnesium be given to every migraineur? No. Journal of neural transmission. 2012; 119 (5): 581-585.

23. Welch Kma, Tepley N, Barkley G, Ramadan NM. The concept of migraine as a state of central neuronal hyperexcitability. Neurol Clin. 1990; 8: 817-828.

24. Möykkynen, T; Uusi-Oukari, M; Heikkilä, J; Lovinger, D. M; Lüddens, H; Korpi, E. R. Magnesium potentiation of the function of native and recombinant GABAA receptors. Neuroreport. 2001; 12(10): 2175-2179.

25. Guerrera MP, Volpe SL, Mao JJ. Therapeutic uses of magnesium. Am Fam Physician. 2009; 80:157-162.

26. Facchinetti F, Sances G, Borella P, Genazzani AR, Nappi G. Magnesium prophylaxis of menstrual migraine: effects on intracellular magnesium. Headache. 1991; 31:298-301.

27. Taubert K. Magnesium in migraine. Results of a multicenter pilot study. Fortschr Med. 1994; 112: 328-330.

28. Peikert A, Wilimzig C, Kohne-Volland R. Prophylaxis of migraine with oral magnesium: results from a prospective, multicenter, placebo-controlled and double-blind randomized study. Cephalalgia. 1996; 16:257-263.

29. Koseoglu E, Talaslioglu A, Gonul AS, Kula M. The effects of magnesium prophylaxis in migraine without aura. Magnes Res. 2008; 21:101-108.

30. Ishii, K; Sasaki, M; Kitagaki, H; Sakamoto, S; Yamaji, S; Maeda, $\mathrm{K}$. Regional difference in cerebral blood flow and oxidative metabolism in human cortex. Journal of nuclear medicine, 1996; 37(7): 1086-1088.
31. Loessner, A; Alavi, A; Lewandrowski, K. U; Mozley, D; Souder, E; Gur, R. E. Regional cerebral function determined by FDGPET in healthy volunteers: normal patterns and changes with age. Journal of Nuclear Medicine.1995; 36(7): 1141-1149.

32. Lodi, R; Kemp, G. J; Pierangeli, G; Cortelli, P; Iotti, S; Radda, G. K; Barbiroli, B. Quantitative analysis of skeletal muscle bioenergetics and proton efflux in migraine and cluster headache. Journal of the neurological sciences. 1997; 146(1): 73-80

33. Sangiorgi, S; Mochi, M; Riva, R; Cortelli, P; Monari, L; Pierangeli, G; Montagna, P. Abnormal platelet mitochondrial function in patients affected by migraine with and without aura. Cephalalgia. 1994; 14(1), 21-23.

34. Schulz, U. G; Blamire, A. M; Davies, P; Styles, P; Rothwell, P. $\mathrm{M}$. Normal cortical energy metabolism in migrainous stroke: A ${ }^{31}$ P-MR spectroscopy study. Stroke. 2009; 40(12): 37403744.

35. Uncini, A; Lodi, R; Di Muzio, A; Silvestri, G; Servidei, S; Lugaresi; et al. Abnormal brain and muscle energy metabolism shown by ${ }^{31} \mathrm{P}-\mathrm{MRS}$ in familial hemiplegic migraine. Journal of the neurological sciences. 1995; 129(2), 214-222.

36. Pfaffenrath $\mathrm{V}$, Wessely $\mathrm{P}$, Meyer $\mathrm{C}$, Isler HR, Evers $\mathrm{S}$, Grotemeyer KH, Taneri Z, Soyka D, Gobel H, Fischer M. Magnesium in the prophylaxis of migraine-a double-blind placebo-controlled study. Cephalalgia. 1996; 16:436-440.

37. Wang F, Van Den Eeden SK, Ackerson LM, Salk SE, Reince $\mathrm{RH}$, Elin RJ. Oral magnesium oxide prophylaxis of frequente migrainous headache in children: a randomized, doubleblind, placebo-controlled trial. Headache. 2003; 43: 601-610.

38. Maizels $M$, Blumenfeld A, Burchette R. A combination of riboflavin, magnesium, and feverfew for migraine prophylaxis: a randomized trial. Headache. 2004; 44:885-8. 